\title{
Mites occurrence on Pachira aquatica Aubl. including aspects of external mouthpart morphology of Brachytydeus formosa (Acari: Tydeidae)
}

\author{
J. R. Lorençon ${ }^{a}$, S. C. Andrade ${ }^{a}$ and D. J. Andrade ${ }^{a *}$ \\ aPrograma de Pós-graduação em Agronomia (Entomologia Agrícola), Laboratório de Acarologia, Departamento de \\ Fitossanidade, Faculdade de Ciências Agrárias e Veterinárias, Universidade Estadual de São Paulo - UNESP, \\ Via de Acesso Prof. Paulo Donato Castellane, s/n, CP 14884-900, Jaboticabal, SP, Brazil \\ *e-mail: danieldwv@yahoo.com.br
}

Received: August 18, 2014 - Accepted: November 11, 2014 - Distributed: February 29, 2016

(With 5 figures)

\begin{abstract}
Pachira aquatica Aubl. is commonly used as an ornamental plant in urban areas of Brazil. The objective of the study was to investigate the occurrence of mites on P. aquatica, with emphasis on Brachytydeus formosa (Cooreman), and to describe aspects the external features of its mouthpart. The study was conducted in 2012 in Jaboticabal, State of São Paulo, Brazil. Ten trees of $P$. aquatica were selected for the experiment. Approximately 130 leaflets were collected from each tree, which were located in different quadrants (north, south, east, and west) and strata (upper, middle, and lower). The leaflets were placed in paper bags and transported to the laboratory. The mites were prepared on optical microscope slides. A total of eleven species of mites were found, belonging to eight different families. The species and genera of the organisms included B. formosa, Eutetranychus banksi (McGregor), Agistemus sp., Tyrophagus putrescentiae (Schrank, 1781), Brevipalpus phoenicis (Geijskes), Brevipalpus sp., Cheletogenes sp., Iphiseiodes zuluagai Denmark \& Muma, Euseius sp., Neoseiulus sp., and only one specimen from the Bdellidae family. The predominant species was $B$. formosa, with 8,142 mites equally distributed among the four quadrants and mostly in the middle and upper strata of the plant. B. formosa mites from leaflets of $P$. aquatica were separated for the study of the external mouthpart morphology by scanning electron microscopy (SEM).
\end{abstract}

Keywords: Tydeoidae, gnathosoma, Eutetranychus banksi, biodiversity, ornamental plant.

\section{Ocorrência de ácaros em Paquira aquatica Aubl. incluindo aspectos morfológicos do aparato bucal de Brachytydeus formosa (Acari: Tydeidae)}

\section{Resumo}

Pachira aquatica Aubl. é frequentemente utilizada como planta ornamental em áreas urbanas no Brasil. O objetivo do trabalho foi conhecer os ácaros associados a P. aquatica com ênfase em Brachytydeus formosa (Cooreman), bem como descrever alguns aspectos morfológicos do seu aparato bucal. O estudo foi realizado em 2012, em Jaboticabal, estado de São Paulo, Brasil. Foram selecionadas dez árvores de P. aquatica para realização do experimento. Cerca de 130 folíolos foram coletados de cada árvore localizados em diferentes quadrantes (norte, sul, leste e oeste) e estratos (superior, médio e inferior). Os folíolos foram colocados em sacos de papel e transportados para o laboratório. Os ácaros foram preparados em lâminas de microscopia óptica. No total foram encontradas onze espécies de ácaros, pertencentes a oito famílias. As espécies encontradas foram B. formosa, Eutetranychus banksi (McGregor), Agistemus sp., Tyrophagus putrescentiae (Schrank, 1781), Brevipalpus phoenicis (Geijskes), Brevipalpus sp., Cheletogenes sp., Iphiseiodes zuluagai Denmark \& Muma, Euseius sp., Neoseiulus sp., e apenas um exemplar da família Bdellidae. A espécie predominante foi $B$. formosa, com 8.142 ácaros igualmente distribuídos nos quatro quadrantes e principalmente nos estratos médio e superior da planta. Ácaros de B. formosa dos folíolos de P. aquatica foram separados para o estudo da morfologia externa do aparato bucal utilizando-se microscopia eletrônica de varredura (SEM).

Palavras-chave: Tydeoidae, gnatossoma, Eutetranychus banksi, biodiversidade, plantas ornamentais

\section{Introduction}

Pachira aquatica Aubl. is frequently used as an ornamental plant in urban areas of Brazil. P. aquatica is generally known as monguba (Brazil), Malabar chestnut, and Guiana chestnut. It belongs to the Malvaceae family and is native to Central and South America. It can grow up to a height ranging from 6 to 14 metres; it possesses 
palmate leaves consisting of 5 to 7 leaflets, and its flowers are large with various white petals with reddish or pinkish tips. Its fruit is similar to that of the true cocoa plant, Theobroma cacao L., although its seeds are released after the flowers have completely dried at the branch ends and not on the stalk (Reis et al., 2012). The nuts produced by $P$. aquatica are rich in various oils, fatty acids, proteins, lipids, and carbohydrates, and are used as a component in cosmetics and as an additive in animal and human food items (Jorge and Luzia, 2012).

Pachira aquatica is, however, also recognized for its high levels of mites on its leaves. Feres et al. (2009) found different mites living on P. aquatica, noting Brachytydeus formosa (Cooreman) (André, 2005; Silva et al., 2013). This mite is a member of the Tydeidae family, commonly known as the yellow mite or the citrus yellow mite, and thrives on the leaves of various plants, mainly trees. The $B$. formosa species was described in 1958 after the collection of material from citrus plants in Morocco (Cooreman 1958). In Brazil, B. formosa has been reported to occur on different plants such as Sechium edule (Jacq.) Swartz, Dahlia sp., Pyrus sp., Carica papaya L., Mangifera indica L., Hevea brasiliensis L., Coffea sp., Cola acuminata (Beauv.) Schott \& Endl., Araucaria angustifolia (Bertol.) Kuntze, P. aquatica, Tecoma stans (L.) Juss. ex Kunth, Bauhinia variegata L., Tabebuia roseo-alba (Ridl.) Sandwith (Flechtmann, 1973; Feres, 2000; Feres et al., 2002; Feres et al., 2003; Daud et al., 2007; Feres et al., 2009; Romero et al., 2011).

The mites of the Tydeidae family present a wide geographic distribution, generally occurring in various countries across the world (Baker, 1968; André, 2011; Silva et al., 2014). It is believed that Tydeidae mites descend from a group of free-living mites that thrive in soil (André and Fain, 2000; Silva et al., 2014). The Tydeidae family has adapted various feeding habits. For example, these are known fungivores, phytophagous predators, and scavengers (Baker, 1965; Wiggers et al., 2005; Tilney et al., 2012). The Tydeidae are considered primitive Prostigmata (André and Fain, 2000). They present a biological cycle composed of six stages (egg, larva, protonymph, deutonymph, trytonymph, and adult) (Hernandes et al., 2006). They possess reduced fixed digits, movable digits similar to a fine needle, and short, fused chelicerae (André, 1981; Kaźmierski, 1989; Silva et al., 2014).

Some species of Tydeidae are considered agricultural pests and can eventually cause economic and environmental loss, whereas others are identified as agriculturally beneficial (André, 2011; Hernandes et al., 2006; Tilney et al., 2012). Existing information on the feeding habits of $B$. formosa remains controversial, as there are doubts on its phytophagy (Smirnoff, 1957; Badii et al., 2001). On the leaves and fruit of the orange plant, one can observe mild discolouration of the tissue at the site of B. formosa (Aguilar et al., 2001). However, Mendel and Gerson (1982) and Walter and Proctor (2013) have reported that $B$. formosa is not a phytophagous species because these feed on true fungi, pollen, and sugary secretions produced by hemipterans and on the eggs and larvae of the Aculops pelekassi (Keifer) mite. In Algeria, Thoreau-Pierre (1977) observed that B. formosa feeds on the remains and pupa of Aleyrodes sp., scalesof both dead and live insects, and even on its own exuviae.

Brachytydeus formosa appear to be attracted by honeydew excreted by hemiptera that favour fungal growth and consequently serve as food for mite, acting as a plant cleanser (Ueckermann and Smith-Meyer, 1979). Upon assessing mites as A. pelekassi predators, Aguilar et al. (2001) verified that $B$. formosa showed an affirmative response. This was probably the first evidence of $B$. formosa feeding on another species of mites.

The objective of the study was to examine the occurrence of mites on P. aquatica, with an emphasis on B. formosa, to clarify aspects of its external mouthpart morphology.

\section{Material and Methods}

Our research was conducted in 2012 at the São Paulo State University, College of Agricultural and Veterinary Sciences (FCAV/UNESP) campus, Brazil.

Ten $P$. aquatica trees were marked and after ten leaflets were collected from the north, south, east, and west quadrant, from the upper, middle, and lower strata, all from the internal region of the tree. A total of 130 leaflets were thus collected from each tree. To conduct the collection of leaflets, a $30 \mathrm{~cm}$ long scissors was used, equipped with a 3 metre long aluminium extensible cable. After collection, the samples were conditioned in paper bags and transported to the laboratory. In the laboratory, the mites detected on the leaflets were examined under a stereomicroscope.

The collected mites were mounted on microscopic slides with Hoyer's medium and immediately placed in an incubator for drying at a temperature of $45^{\circ} \mathrm{C}$ (Krantz and Walter, 2009). After 4 days, the slides were removed from the incubator and sealed with colourless enamel. Through the use of a dichotomous key and microscope phase contrast optics, mites were identified. The slides were deposited in the collection belonging at FCAV-UNESP. The obtained data for the most frequently occurring mites [B. formosa and Eutetranychus banksi (McGregor)] were submitted for variance analysis, and means were compared using the Tukey test to determine the spatial distribution of mites on $P$. aquatica.

Brachytydeus formosa were collected from P. aquatica leaves to study the morphology of its external mouthpart by scanning electron microscopy (SEM). The mites were fixed in flasks containing 3\% glutaraldehyde in $0.1 \mathrm{M}$ potassium phosphate buffer $(\mathrm{pH} 7.4)$ for $72 \mathrm{~h}$. Subsequently, mites were post-fixed in $2 \%$ osmium tetroxide for $4 \mathrm{~h}$. The dried adult mites were placed on aluminium stubs that were covered with double-sided carbon tape, coated with a $35 \mathrm{~nm}$ gold layer, and examined by SEM [JEOL JSM - 6610 LV $(20 \mathrm{kV})$ ].

\section{Results}

A total of 8,861 mites were collected, representing 11 different species and belonging to eight families. The species and genera of the collected mites included 
B. formosa, E. banksi, Agistemus sp., Tyrophagus putrescentiae (Schrank), Brevipalpus phoenicis (Geijskes), Brevipalpus sp., Cheletogenes sp., Iphiseiodes zuluagai Denmark \& Muma, Euseius sp., Neoseiulus sp. and only one mite from the Bdellidae family. The predominant species in this survey was B. formosa, with 8,142 mites representing $92 \%$ and $E$. banksi with 197 specimens, representing $2.2 \%$ of the total.

Brachytydeus formosa were predominantly found (above $99 \%$ ) on the abaxial surface of $P$. aquatica leaves.
The highest incidence of $B$. formos $a$ was observed in the upper and middle strata of the plants (Figure 1). The lower stratum presented a reduced concentration of $B$. formosa, significantly different from the other strata (Table 1). No differences were observed between the quadrants (Table 1). The total number of $B$. formosa for the quadrants was 2,894 mites (south), 1,984 (west), 1,766 (north) and 1,534 (east).

The number of $E$. banksi infesting on $P$. aquatica did not differ among strata and quadrants (Table 1).
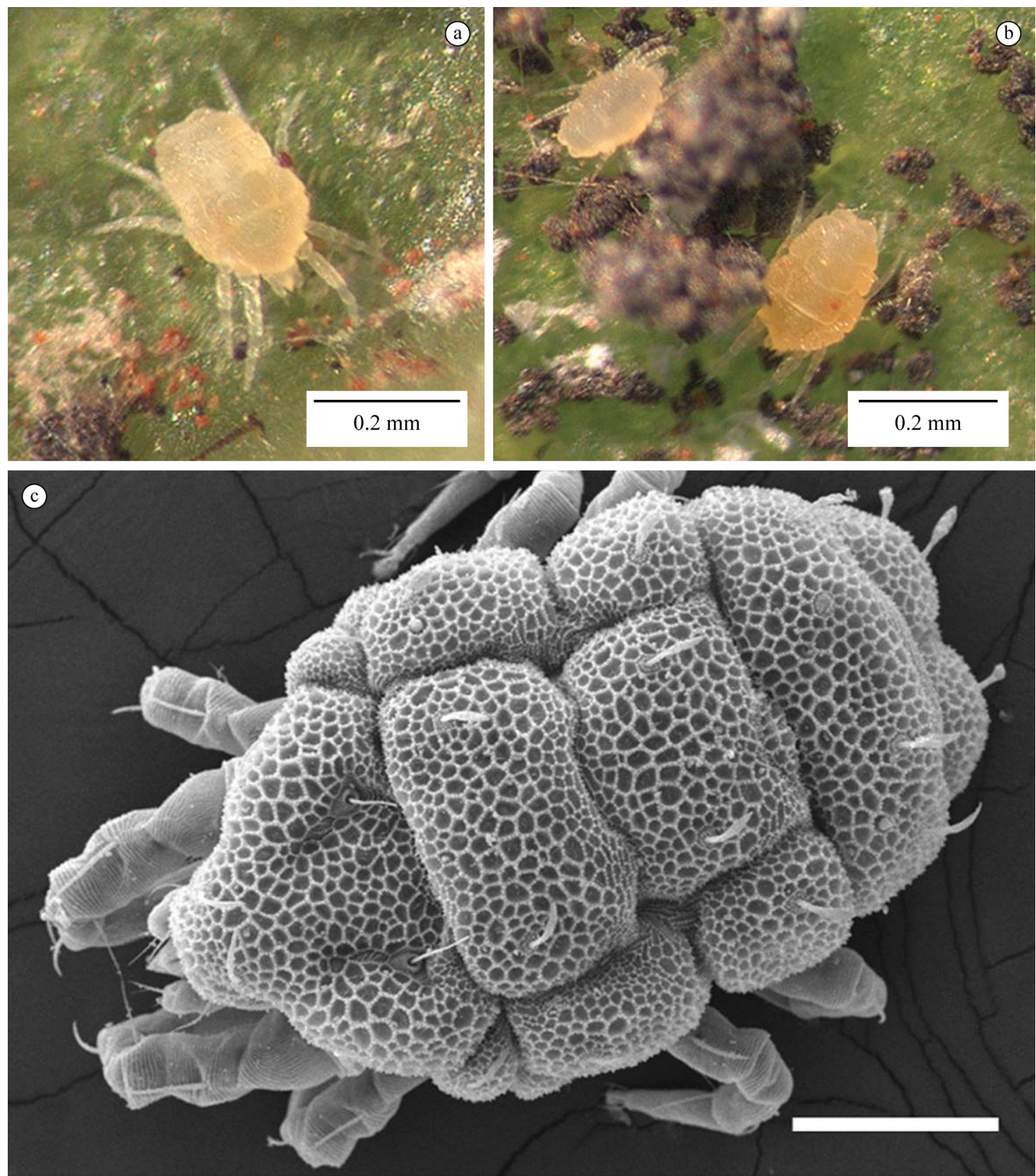

Figure 1. (a-b) Mites Brachytydeus formosa feeding on Paquira aquatica leaves in Jaboticabal-SP, Brazil. Note in Figure b the presence of opportunistic fungi on the honeydew of Bemisia tabaci; (c) SEM micrographs of B. formosa. Scale bar: $50 \mu \mathrm{m}$. 
Table 1. Variance analysis and significance test for the number of Brachytydeus formosa and Eutetranychus banksi mites in different plant areas of Paquira aquatica. Jaboticabal, 2012.

\begin{tabular}{ccc}
\hline Stratum & B. formosa & E. banksi \\
\hline Upper (1) & $4.57 \mathrm{a}$ & $1.77 \mathrm{a}$ \\
Middle (2) & $4.14 \mathrm{a}$ & $1.92 \mathrm{a}$ \\
Lower (3) & $3.27 \mathrm{~b}$ & $1.75 \mathrm{a}$ \\
Stratum & $12.09^{* *}$ & $1.95^{\mathrm{NS}}$ \\
C.V. (\%) & 15.09 & 11.75 \\
PSD & 0.66 & 0.23 \\
Quadrant & & \\
East (1) & $3.77 \mathrm{a}$ & $1.78 \mathrm{a}$ \\
West (2) & $4.16 \mathrm{a}$ & $1.68 \mathrm{a}$ \\
North (3) & $4.00 \mathrm{a}$ & $1.71 \mathrm{a}$ \\
South (4) & $4.29 \mathrm{a}$ & $1.98 \mathrm{a}$ \\
Quadrant & $1.27^{\mathrm{NS}}$ & $2.52^{\mathrm{NS}}$ \\
C.V. (\%) & 15.49 & 14.9 \\
PSD & 0.75 & 0.32
\end{tabular}

NS - not significant. ${ }^{* *}$ significant at $1 \%$ of probability. Means presented in this table were obtained through the original data transformed into $\ln (x+5)$. Means followed by the same letter in the column, do not differ from each other using the Tukey test, at $5 \%$ probability. C.V. Coefficient of variation.

We found $75 \mathrm{E}$. banksi mites in the south quadrant, 54 in the east, and 51 in the north. Figure 2 presents a summary of all mites found on each plant. Mites ocurrence was not the same in all plants. One can observe that on plant 4 was registered the largest number of $B$. formosa, with a total of 1,305 mites and for E. banksi largest population was observed on plant 3 (43 mites).

Brachytydeus formosa presents palps with 4 segments (trochanter, femur-genu, tibia, tarsus) (Figure 3), reduced fixed digits, movable serrated digits that are used to perforate food, and fused chelicerae bases that were arranged one on top of the other. The subcapitulum of B. formosa consists of three pairs of characteristic adoral setae; the movable digits orifice were clearly visible (Figure 4). The capitulum tissue was ornamented with longitudinal striae, with a cavity between the chelicerae junctions that presents a standard ornamentation (Figure 4c). Upon ventral observation of the capitulum, one can see the hypostome and the subcapitulum clearly showing the subcapitular setae (Figure 5a). We observed two pairs the adoral setae (Figure 5b).

\section{Discussion}

We observed that $P$. aquatica plants present a large leaflet area that provides shade to the inside of the plant and serves as a highly favourable microclimate for the development of fungi, lichen, and algae (Figure 1a, b). It is highly likely that these fungi, lichen, and algae would be consumed by $B$. formosa, thus partly explaining its high incidence.

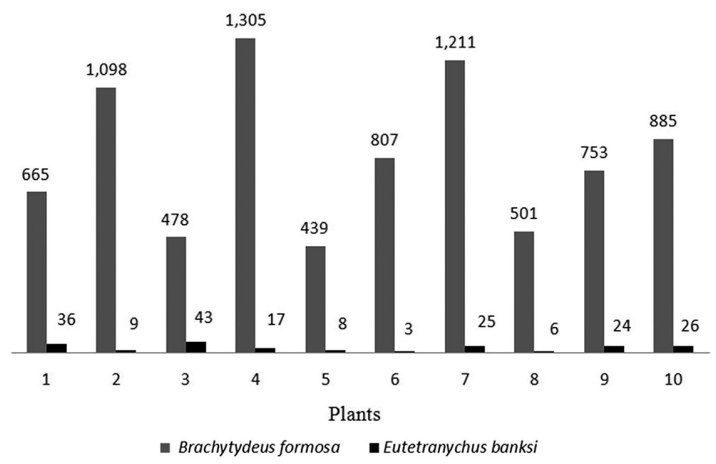

Figure 2. Total number of Brachytydeus formosa and Eutetranychus banksi mites found per plant.

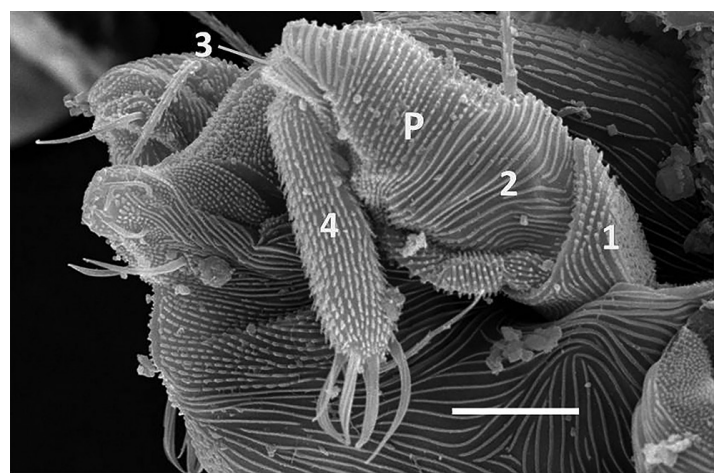

Figure 3. Brachytydeus formosa palp showing four segments. P: Palp. 1: trochanter. 2: femur-genu. 3: tibia. 4. tarsus. Scale bar: $10 \mu \mathrm{m}$.

Phytophagous and predatory species were registered on $P$. aquatica plants. However, another aspect worth mentioning was the small number of predatory mite found in relation to the population of $B$. formosa. The population dimension of mites has been previously associated with low environmental heterogeneity, high food availability, and low number of natural enemies, which favours the growth and development of phytophagous mite (Altieri et al., 2003).

Brachytydeus formosa was predominantly found on the leaflets abaxial surface of $P$. aquatic on the fungi that grow from honeydew produced by the whitefly, Bemisia tabaci (Gennadius). Therefore, is likely that $B$. formosa prefers abaxial surface due the most availability of food and lower solar incidence. Smirnoff (1957) observed that the quantity of $B$. formosa was directly correlated with the presence of honeydew produced by cochineals on citrus plants. The author realised that the fungi (mycelium) present on the honeydew, also commonly known as sooty mould, attracted the mite. The larvae and protonymphs of Tydeus californicus (Banks) feed primarily on honeydew aphids, where as other stages feed on apple trees (Bayan, 1986). Tydeinae mite are commonly found on moss, fungi, decomposing material, hay, soil (principally in the organic part), bird nests, stored products, and the aerial section of plants (Walter and Proctor, 2013). 


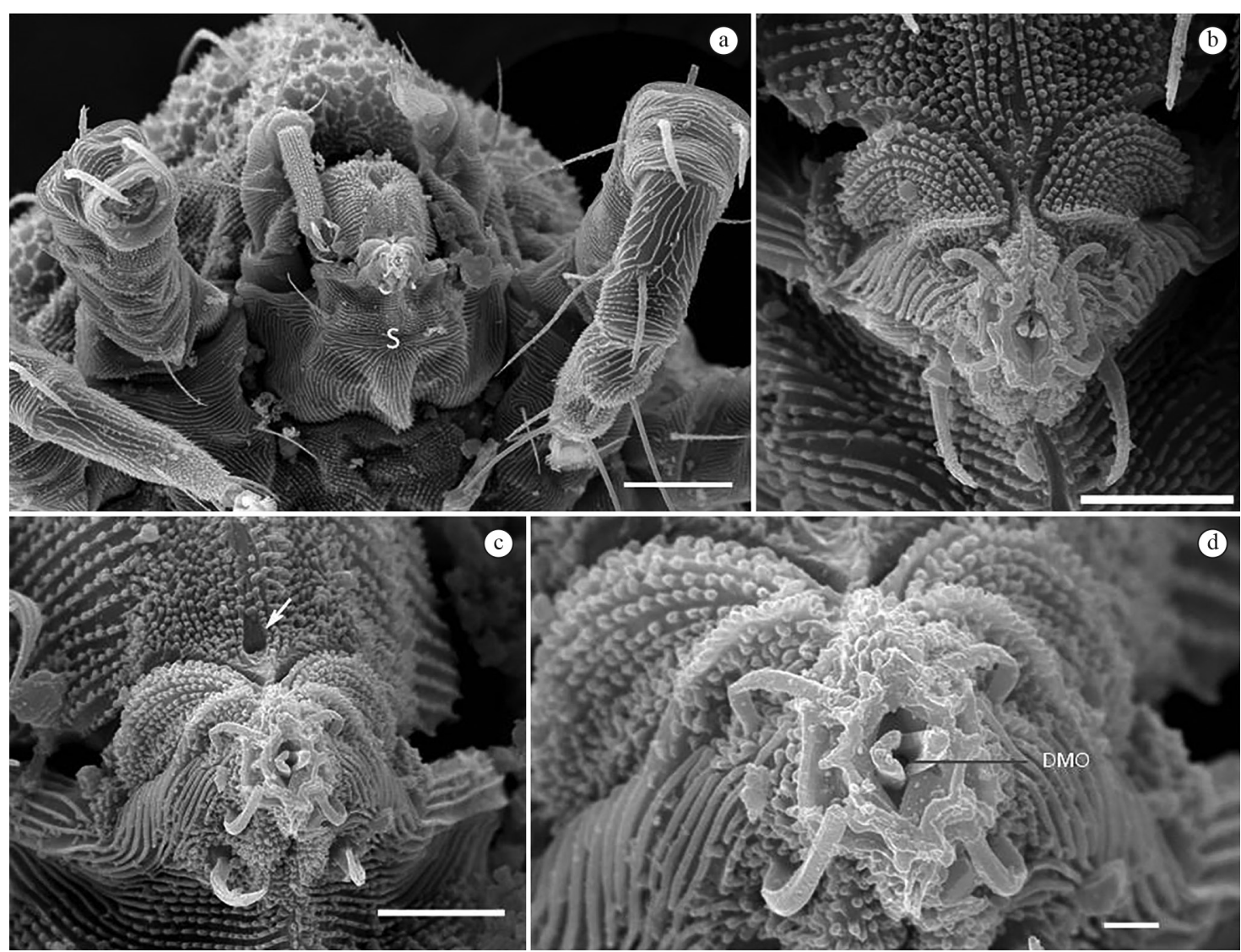

Figure 4. Frontal view of gnathosoma of Brachytydeus formosa. (a) S: subcapitulum (infracapitulum). Scale bar: 10 $\mu \mathrm{m}$; (b) Scale bar: $5 \mu \mathrm{m}$; (c) Arrow indicates ornamentation at the junction of two chelicerae. Scale bar: $10 \mu \mathrm{m}$; (d) Apex of gnathosoma. DMO: movable digits orifice. Scale bar: $1 \mu \mathrm{m}$.
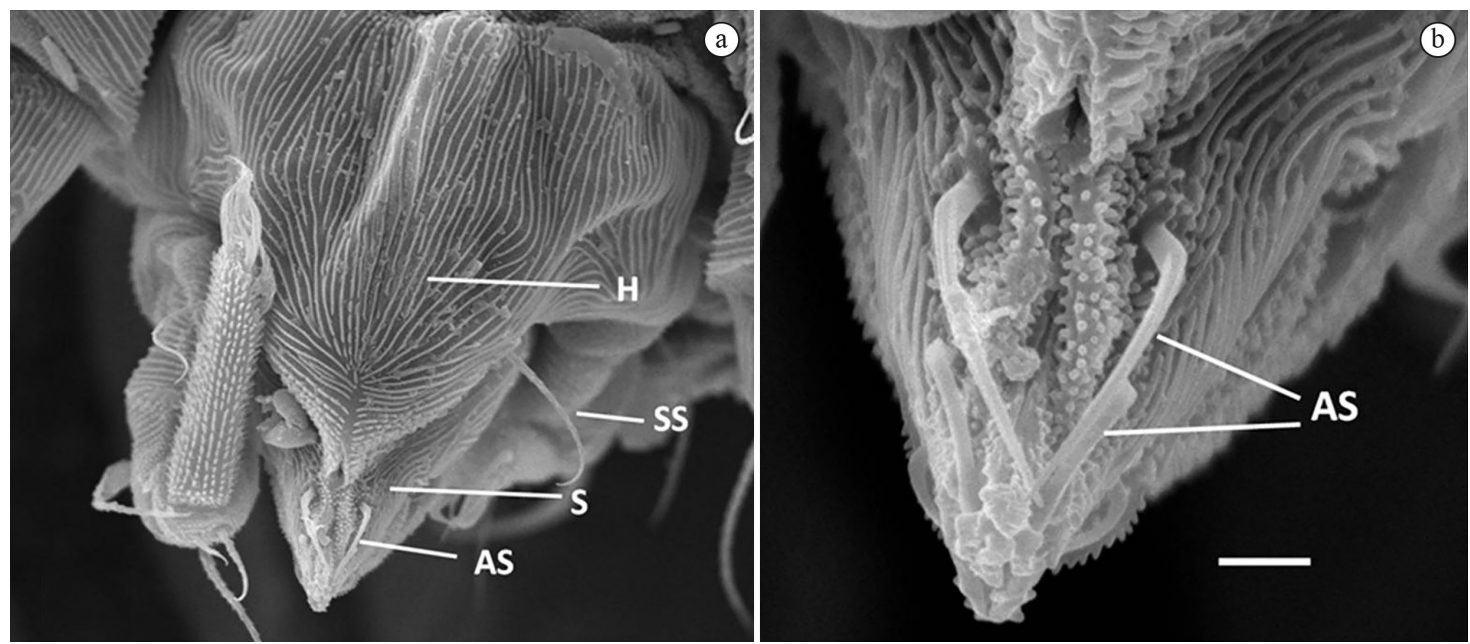

Figure 5. Ventral view of gnathosoma of Brachytydeus formosa.(a) H: hypostome; HS: subcapitular setae; S: subcapitulm (infracapitulum); AS: adoral setae. Scale bar: $10 \mu \mathrm{m}$; (b) Detail of the three pairs of subcapitular setae or adoral setae. Scale bar: $2 \mu \mathrm{m}$.

The largest number of $B$. formosa mites in the upper and middle strata can be related to the preference of this mite by young and mature leaves. We observed that $P$. aquatica plants in lower stratum present a higher concentration of senescent leaves. We confirmed also that the colonies of $B$. formosa principally gathered along the length of central and secondary veins. Bellini et al. (2008) also observed this phenomenon, in which $B$. formosa mainly thrived at the 
base of leaflets, specifically at the central vein junctions harbouring secondary veins.

Evaluation studies of macrofauna in P. aquatica plants in the northwest region of São Paulo State (Brazil) conducted by Feres et al. (2009) showed that the predominant mites also included B. formosa and E. banksi. Upon assessment of mites diversity in Bauhinia variegata L. in the northwest state of São Paulo, Daud et al. (2007) reported that $B$. formosa was the predominant species. Bellini et al. (2008) also stated that B. formosa was phytophagous, frequently occurring on the leaves of the rubber tree and spontaneously or naturally thriving on the leaves of herbaceous Euphorbiaceae such as Chamaesyce hirta (L.) Millsp., Chamaesyce hyssopifolia (L.) Small., Euphorbia heterophylla L., and Phyllanthus tenellus Roxb. Feres et al. (2010) registered Brachytydeus sp. as one of the most common phytophagous mite occurring on Hymenaea martiana Hayne.

Walter and Proctor (2013) commented on the difficulties involved in clarifying the feeding habits of tydeinae mites. For example, previous reports (Baker and Wharton, 1952; Rizk et al., 1979) have considered T. californicus as a predator. In contrast, Fleschner and Arakawa (1953) have described the same mite as phytophagous. The information on $B$. formosa is also controversial. Jeppson et al. (1975), as cited by Krantz and Walter (2009), believe that $B$. formosa is a fungivore. Aguilar et al. (2001), however, reported that the mild discolouration occurring in the leaves and fruits of orange trees were attributable to $B$. formosa. On the other hand, Mendel and Gerson (1982) earlier showed that the occurrence of $B$. formosa on citrus plants was beneficial because it feeds on the sooty mould that grows on leaves, thus clearing the plant of this microbe.

The tydeinae Tydeus caudatus (Duge's) was previously reported as a secondary pest to apple trees in Germany, specifically its leaves and fruits (Karg, 1971). One mite of the Tydeus genus (species not identified) has been reported as the primary cause of vein decolouration (Malchenkova, 1967; cited by Krantz and Lindquist, 1979). However, Krantz and Lindquist (1979) did not reject the concept of phytophagy in Tydeidae, specifically in Brachytydeus, Paralorryia, and Tydeus, as the authors believe that the green colour observed in the interior of the mite body clearly indicates absorption of chlorophyll-containing plant material. Hernandes et al. (2006) previously described the biology of $B$. formosa on rubber tree leaves. That study was carried out with a diet of rubber tree leaf discs, and there was full development of female mite with an egg to adult mean duration of 16.42 days and longevity of 37.43 days.

Krantz and Lindquist (1979) and Krantz and Walter (2009) have reported that $T$. californicus was a predator of citrus mite Aceria sheldoni (Ewing), similar to the phytophagous mite of the avocado, based on the observation that it feeds on the honeydew produced by aphids. On the other hand, McCoy et al. (1969) demonstrated that Parapronematus acaciae Baker does not prey on eriophyid and tetranychid mites, but on citrus leaf fungi. Calvert and Huffaker (1974) and Flaherty and Hoy (1972) observed that Pronematus genus reproduce when offered a dietof Typha domingensis pollen grains. According to Krantz and Lindquist (1979), the abundance of Tydeidae on the crown of trees could be explained by the occurrence of pollen deposits on leaves deposited by the wind. On the other hand, studies have indicated that $B$. formosa phytophagy might be another feeding strategy (Krantz and Walter, 2009; Walter and Proctor, 2013).

Electron micrographs of mite mouthpart besides assisting in taxonomy and morphology studies can also assist in better understanding the feeding behaviour of these organisms. Our electron micrographs of $B$. formosa gnathosoma allowed to observe clearly the present structures (Figures 3, 4 and 5). The lack of feeding specialisation and mouthpart modification in B. formosa suggests that evolution is necessary for obligatory phytophagy. In this way, the lack of feeding specialisation and mouthpart changes, especially of serrated movable digits, suggests that B. formosa might be in the middle of an evolutionary transition and that obligatory phytophagy appears to be the next stage for this group (Krantz and Lindquist, 1979; André and Fain, 2000; Nuzzaci and Di Palma, 2002; Krantz and Walter, 2009).

Lindquist (1998) clearly showed that in some Trombidiform lineages, the chelicerae were modified to stylets that were used to perforate the surface of plants and to extract the cellular content of plants. Furthermore, Lindquist (1998) described that phytophagy appeared at least seven times among the Trombidiform lineages. Phytophagy might thus be a more recently acquired type of facultative behaviour in the Tydeoidea lineage. Krantz and Lindquist (1979) presented a very interesting review on the evolution of phytophagous mites in the development of feeding habits and gnathosoma structures. According to these authors, Tydeidae phytophagy is not obligatory and thus suggesting adaptation to fungivory, which emerged from a primitive predatory feeding habit.

A previous study examined the ultrastructural features and the function of the gnathosoma in Tydeus sp. (Tydeidae) (Nuzzaci and Di Palma, 2002), describing that the subcapitulum and chelicerae bases were not fused, but instead were very close to each other. The Tydeus sp. food channel also had dorsal scales, and the labrum was a unique structure that preserved the structure of the cheliceral stylets. The fixed digits and the basal cheliceral segments were moulded to stick to the lateral lips and did not form a stylophore similar to that in Tetranychidae. The movable digits were similar to needles; these were positioned at the end of the gnathosoma and proximally articulated with a large lever that were equipped with two strong knobby apodemes (Nuzzaci and Di Palma, 2002). Tetranychoidea modifications are particularly different because these possess a retractable stylophore, a pair of setae that function as compact needles that perforate plant cells, and move by retraction and protraction of the stylophore (Hislop and Jeppson, 1976; Lindquist, 1998).

To determine the true function of plant materials in this group of mites, future investigations should utilized other approaches such as molecular tests (DNA and PCR), molecular markers, and radioactive isotopes. 


\section{Acknowledgements}

We would like to extend our gratitude to the Electron Microscope Laboratory of the Department of Cellular Biology of USP, Ribeirão Preto and to Prof. Dr. Gilberto José de Moraes (ESALQ-USP, Piracicaba) and Prof. Dr. Reinaldo José Fazzio Feres (IBILCE-UNESP, S.J. do Rio Preto) for his help in image interpretation.

\section{References}

AGUILAR, H., CHILDERS, C.C. and WELBOUM, W.C., 2001. Relative abundance and seasonal occurrence of mites in the family Tydeidae on citrus in Florida. In: R.B. HALLIDAY, D.E. WALTER, H.C. PROCTOR, R.A. NORTON and M.J. COLLOFF. Proceedings of the 10th International Congress of Acarology, 2001, Melbourne. Melbourne: CSIRO Publishing, pp. 376-380.

ALTIERI, M.A., SILVA, E.N. and NICHOLLS, C.I., 2003. O papel da biodiversidade no manejo de pragas. Ribeirão Preto: Holos. 226 p.

ANDRÉ, H.M. and FAIN, A., 2000. Phylogeny, ontogeny and adaptive radiation inthe superfamily Tydeoidea (Acari: Actinedida), with a reappraisal of morphological characters. Zoological Journal of the Linnean Society, vol. 130, no. 3, pp. 405-448. http://dx.doi. org/10.1111/j.1096-3642.2000.tb01636.x.

ANDRÉ, H.M., 1981. A generic revision of the family Tydeidae (Acari: Actinedida). II. Organotaxy of the idiosoma and gnathosoma. Acarologia, vol. 22, pp. 31-46.

ANDRÉ, H.M., 2005. In search of the true Tydeus (Acari, Tydeidae). Journal of Natural History, vol. 39, no. 13, pp. 975-1001. http:// dx.doi.org/10.1080/00222930400002838.

ANDRÉ, H.M., 2011. Dugès' caudatusis a tenuipalpidae and not a tydeidae (acari). Acarologia, vol. 51, no. 1, pp. 69-85. http:// dx.doi.org/10.1051/acarologia/20111990.

BADII, M.H., FLORES, A.E., PONCE, G., LANDEROS, J. and QUIROZ, H., 2001. Does the Lorryia formosa Cooreman (Acari: Prostigmata: Tydeidae) population visit or reside on citrus foliage? Proceedings of the 10th International Congress of Acarology, 2001, Melbourne. Melbourne: CSIRO Publishing, pp. 413-418.

BAKER, E.W. and WHARTON, G.W., 1952. An introduction to Acarology. New York: MacMillan. p. 465.

BAKER, E.W., 1965. A review of the genera of the family Tydeidae (Acarina). Advances in Acarology, vol. 2, pp. 95-133.

BAKER, E.W., 1968. The genus Lorryia. Annals of the Entomological Society of America, vol. 61, no. 4, pp. 986-1008. http://dx.doi. org/10.1093/aesa/61.4.986.

BAYAN, A., 1986. Tydeid mites associated with apples in Lebanon (Acari: Actinedida: Tydeidae). Acarologia, vol. 27, pp. 311-316.

BELLINI, M.R., FERES, R.J.F. and BUOSI, R., 2008. Ácaros (Acari) de seringueira (Hevea brasiliensis Muell. Arg., Euphorbiaceae) e de euforbiáceas espontâneas no interior dos cultivos. Neotropical Entomology, vol. 37, no. 4, pp. 463-471. http://dx.doi.org/10.1590/ S1519-566X2008000400016. PMid:18813750.

CALVERT, D.J. and HUFFAKER, C.B., 1974. Predator (Metaseilus occidentalis) - prey (Pronematus spp.) interactions under sulfur and cattail pollen applications in a noncommercial vineyard. Entomophaga, vol. 19, no. 3, pp. 361-369. http://dx.doi. org/10.1007/BF02371062.

DAUD, R.D., FERES, R.J.F. and BUOSI, R., 2007 [viewed 15 July 2012]. Ácaros (Arachnida: Acari) Associados a Bauhinia variegata L. Leguminosae) no Noroeste do Estado de São Paulo. Neotropical Entomology [online], vol. 36, pp. 322-325. http:/ www.scielo.br/pdf/ne/v36n2/a25v36n2.pdf.

FERES, R.J.F., BELLINI, M.R. and ROSSA-FERES, D.C., 2003. Ocorrência e diversidade de ácaros (Acari, Arachnida) associados a Tabebuia roseo-alba (Ridl.) Sand (Bignoniaceae), no município de São José do Rio Preto, São Paulo, Brasil. Revista Brasileira de Zoologia, vol. 20, no. 3, pp. 373-378. http://dx.doi.org/10.1590/ S0101-81752003000300002.

FERES, R.J.F., ROSSA-FERES, D.C., DAUD, R.D. and SANTOS, R.S., 2002. Diversidade de ácaros (Acari, Arachnida) em seringueiras (Hevea brasiliensis Muell. Arg., Euphorbiaceae) na Região Noroeste do estado de São Paulo, Brasil. Revista Brasileira de Zoologia, vol. 19, no. 1, pp. 137-144. http://dx.doi. org/10.1590/S0101-81752002000100011.

FERES, R.J.F., RUSSO, V. and DAUD, R.D., 2010. Diversidade de ácaros (Arachnida: Acari) em Hymenaea martiana (Leguminosae) em gradiente de tamanho de plantas. Biota Neotropica, vol. 10, no. 4, pp. 119-126. http://dx.doi.org/10.1590/S1676-06032010000400016.

FERES, R.J.F., VIEIRA, M.R., DAUD, R.D., PEREIRA JUNIOR, E.G., OLIVEIRA, G.F. and DOURADO, C.L., 2009. Ácaros (Arachnida, Acari) de plantas ornamentais na região noroeste do Estado de São Paulo, Brasil: inventário e descrição dos sintomas causados pelos fitófagos. Revista Brasileira de Zoologia, vol. 53, pp. 466-475. http://dx.doi.org/10.1590/S0085-56262009000300024.

FERES, R.J.F., 2000. Levantamento e observações naturalísticas da acarofauna (Acari: Arachnida) de seringueiras cultivadas (Hevea spp., Euphorbiaceae) no Brasil. Revista Brasileira de Zoologia, vol. 17, no. 1, pp. 157-173. http://dx.doi.org/10.1590/ S0101-81752000000100011.

FLAHERTY, D.L. and HOY, M.A., 1972. Biological control of Pacific mites and Willamette mites in San Joaquin Valley vineyards. Part III. Role of tydeid mites. Researches on Popular Ecology, vol. 13, no. 1, pp. 80-96. http://dx.doi.org/10.1007/BF02522015.

FLESCHNER, C.A. and ARAKAWA, K.Y., 1953. The mite Tydeus californicus on citrus and avocado leaves. Journal of Economic Entomology, vol. 45, no. 6, pp. 1092. http://dx.doi. org/10.1093/jee/45.6.1092.

FLECHTMANN, C.H.W., 1973. Lorryia formosa Cooreman, 1958: um ácaro dos citros pouco conhecido no Brasil. Ciencia e Cultura, vol. 25, pp. 1179-1181.

HERNANDES, F.A., FERES, R.J.F. and NOMURA, F., 2006. Biological cycle of Lorryia formosa (Acari, Tydeidae) on rubber tree leaves: a case of thelytoky. Experimental \& Applied Acarology, vol. 38, no. 4, pp. 237-242. http://dx.doi.org/10.1007/s10493006-0014-2. PMid:16612667.

HISLOP, R.G. and JEPPSON, L.R., 1976. Morphology of the mouthparts of several species of phytophagous mites. Annals of the Entomological Society of America, vol. 69, no. 6, pp. 11251135. http://dx.doi.org/10.1093/aesa/69.6.1125.

JORGE, N. and LUZIA, D.M.M., 2012. Caracterização do óleo das sementes de Pachira aquatica Aublet para aproveitamento alimentar. Acta Amazonica, vol. 42, no. 1, pp. 149-156. http:// dx.doi.org/10.1590/S0044-59672012000100017. 
KARG, W., 1971. Untersuchungen über die Acarofauna in Apfelanlagen im Hinblick auf den Übergand von Standardspritzprogrammen zu integrierten Behandleungsmassnahmen. Arch. Pflanzenschutz, vol. 7, no. 4, pp. 243-279. http://dx.doi.org/10.1080/03235407109431783.

KAŹMIERSKI, A., 1989. Revision of the genera Tydeus Koch sensu André, Homotydeus André and Orthotydeus André with description of a new genus and four new species of Tydeidae (Acari: Actinedida: Tydeidae). Mitteilungen aus dem Hamburgischen Zoologischen Museum und Institut, vol. 86, pp. 289-314.

KRANTZ, G.W. and LINDQUIST, E.E., 1979. Evolution of phytophagous mites (Acari). Annual Review of Entomology, vol. 24, no. 1, pp. 121-158. http://dx.doi.org/10.1146/annurev. en.24.010179.001005

KRANTZ, G.W. and WALTER, D.E.A., 2009. Manual of Acarology. 3rd ed. Lubbock: Texas Tech University Press. p. 807.

LINDQUIST, E.E., 1998. Evolution of phytophagy in trombidiform mites. Experimental \& Applied Acarology, vol. 22, no. 2, pp. 81100. http://dx.doi.org/10.1023/A:1006041609774.

MCCOY, C.W., SELHIME, A.G. and KANAVEL, R.F., 1969. The feeding behavior and biology of Parapronematus acaciae (Acarina: Tydeidae). Florida Entomologist, vol. 52, pp. 13-19.

MENDEL, Z. and GERSON, U., 1982. Is the mite Lorryia formosa Cooreman (Prostigmata: Tydeidae) a sanitizing agent in citrus groves? Acta Oecologica, vol. 3, no. 1, pp. 47-51.

NUZZACI, G. and DI PALMA, A., 2002. Mouthparts of a tydeid mite: an ultrastructural and functional investigation. Entomologica, Bari, vol. 36, pp. 71-91.

REIS, N., GONÇALVES, R., DEMÉTRIO, R. and CUNHA, R., 2012 [viewed 15 July 2012]. Árvores do Campus de UFRRJ, Seropédica (RJ): Pachira aquatica Aubl [online]. Available from: http://botanicaufrrj.blogspot.com.br/2011/07/pachiraaquatica-aubl.html.

RIZK, G.A., SOLIMAN, Z.R. and ALI, M.A., 1979. Survey on mites associated with citrus and grape-vine in Minia region, Egypt (Tydeidae). Bulletin de la Societe Entomologique d'Egypte, vol. 62 , pp. $105-110$.

ROMERO, G.D., DAUD, R.D., SALOMÃO, A.T., MARTINS, L.F., FERES, R.J.F. and BENSON, W.W., 2011. Mites and leaf domatia: No evidence of mutualism in Coffea arabica plants. Biota
Neotropica, vol. 11, no. 1, pp. 27-34. http://dx.doi.org/10.1590/ S1676-06032011000100002.

SILVA, G.L., CUNHA, U.S., ROCHA, M.S., PANOU, E.M. and FERLA, N.J., 2014. Tydeid and triophtydeid mites (Acari: Tydeoidea) associated with grapevine (Vitaceae: Vitis spp.) in Brazil, with the descriptions of species of Prelorryia (André, 1980) and Tydeus Koch, 1835. Zootaxa, vol. 3814, no. 4, pp. 495-511. http://dx.doi.org/10.11646/zootaxa.3814.4.3. PMid:24943444.

SILVA, G.L., ROCHA, M.S., REICHERT, M.B. and FERLA, N.J., 2013. A new espécies of the genus Brachytydeus Thor, 1931 sensu André, 2005 (Acari: Tydeidae) from Rio Grande do Sul State, Brazil, with a keyto the species in the Americas. International Journal of Acarology, vol. 39, no. 8, pp. 1-5. http://dx.doi.org/1 $0.1080 / 01647954.2013 .861510$.

SMIRNOFF, W.A., 1957. An undescribed species of Lorryia causing injury to citrus trees in Morocco. Journal of Economic Entomology, vol. 50, no. 3, pp. 361-362. http://dx.doi.org/10.1093/ jee/50.3.361a.

THOREAU-PIERRE, B., 1977. Role de Lorryia formosa (Acarina: Tydeidae) au sein de la biocenose des agrumes, premiere appoche. Institut National Agronomique (Algeria). Annale, vol. 7, pp. 33-35.

TILNEY, P.M., WYK, A.E.V. and MERWE, C.F.V.D., 2012. Structural evidence in Plectroniella armata (Rubiaceae) for possible material exchange between domatia and mites. Plos One, vol. 7, pp. 1-6. http://dx.doi.org/10.1371/journal.pone.0039984.

UECKERMANN, E.A. and SMITH-MEYER, M.K.P., 1979 [viewed 15 July 2012]. African Tydeidae (Acari): The genus Lorryia Oudemans, 1925. Phytophylactica [online], vol. 11, pp. 43-50. Available from: http://bionames.org/references/636c953 d67a9bff00a9c1e29849c8791

WALTER, D.E. and PROCTOR, H.C., 2013. Mites: ecology, evolution and behaviour: life at a microscale. 2 nd ed. Heidelberg: Springer. p. 508.

WIGGERS, S., PRATT, P.D., TIPPING, P.W., WELBOURN, C. and CUDA, J.P., 2005. Within-plant distribution and diversity of mites associated with the invasive plant Schinus terebinthifolius (Sapindales: Anacardiaceae) in Florida. Environmental Entomology, vol. 34, no. 4, pp. 953-962. http://dx.doi.org/10.1603/0046225X-34.4.953. 